\title{
PENGUATAN KAPASITAS GURU MADRASAH MELALUI PROGRAM PELATIHAN PENGEMBANGAN STRATEGI ACTIVE LEARNING DI MADRASAH TSANAWIYAH RAUDHATUL HIKAM NW BANYU URIP PRAYA BARAT
}

\author{
Emawati \\ Uiniversitas Islam Negeri Mataram \\ emawati@uinmataram.ac.id
}

\begin{abstract}
Abstrak: MTs Raudhatul Hikam merupakan satu-satunya madrasah berbasis pesantren di Desa Banyu Urip, Praya Barat, Lombok Tengah. Berdiri sejak tahun 2014, madrasah ini sekarang memiliki peserta didik berjumlah 40 anak dan guru sebanyak 17 orang. Pengelola yayasan dan guru-guru di madrasah ini mayoritas masih berusia muda dan belum banyak pengalaman mengajar. Oleh karenanya pelaksanaan kegiatan pengabdian madrasah binaan terkait peningkatan kapasitas guru sangat diperlukan. Kegiatan pengabdian ini bertujuan untuk mengembangkan kemampuan guru dalam merancang pembelajaran aktif. Metode yang menggunakan dalam pengabdian ini adalah pelatihan dan peer teching. Berdasarkan kegiatan peer teaching menunjukkan bahwa $60 \%$ guru belum terampil menerapkan pembelajaran aktif. Namun setelah diadakan kegiatan pendampingan, monitoring, dan evaluasi secara simultan maka perbaikan dan peningkatan kemampuan mengelola pembelajaran aktif di kelas menjadi meningkat.
\end{abstract}

Kata kunci: madrasah, pelatihan, peer teaching

\begin{abstract}
MTs Raudhatul Hikam is the only pesantren-based madrasa in Banyu Urip Village, Praya Barat, Lombok Tengah. Established in 2014, this madrasa now has 40 students and 17 teachers. The managers of foundations and teachers in the madrasa are mostly still young and have not had much teaching experience. Therefore, the implementation of madrasah service activities related to increasing teacher capacity is very necessary. This community service activity aims to develop the teacher's ability to design active learning. The method used in this service is training and peer teching. Based on peer teaching activities shows that $60 \%$ of teachers have not been skilled in implementing active learning. However, after simultaneous assistance, monitoring and evaluation activities were held, the improvement and improvement of the ability to manage active learning in the classroom increased.
\end{abstract}

Keyword: madrasa, training, peer teaching

\section{Pendahuluan}

Lembaga pendidikan Islam di Indonesia dewasa ini dihadapkan kepada tantangan yang jauh lebih kompleks dibandingkan periode-periode sebelumnya. Disamping berusaha menciptakan muslim yang memahami ilmu-ilmu agama dan umum, lembaga pendidikan Islam juga dihadapkan pada tuntutan untuk terlibat dalam pembentukan manusia Indonesia baru yang modern dan penuh integritas. ${ }^{1}$ Sementara, dalam realitasnya pendidikan Islam di Indonesia tidak terlepas dari berbagai problem. Sutrisno menilai bahwa tiga jenis lembaga pendidikan dasar-menengah di Indonesia, yakni pesantren, sekolah, dan madrasah, masingmasing mengidap penyakit sangat kronis. Pesantren diterpa stigma eksklusif, literal, radikal,

1 Azyumardi Azra dan Jamhari, "Pendidikan Islam Indonesia dan Tantangan Globalisasi: Perspektif Sosio_Historis", dalam Jajat Burhanudin dan Dian Afrianti, Mencetak Muslim Modern, Peta Pendidikn Islam Indonesia (Jakarta: Raja Grafindo Persada, 2006), 17. 
fundamental, teroris, dan semacamnya. Pendidikan Agama Islam di sekolah kebanjiran kritik, seperti model PAI di sekolah terlalu normatif, doktriner, kognitif oriented, dan seterusnya. Madrasah lebih parah lagi, sebagai lembaga yang kurang diperhitungkan, kualitasnya sangat memprihatinkan, $70 \%$ gurunya mismatch, dan sebagainya. ${ }^{2}$

Realitas yang ditengarai Sutrisno tersebut bukan tanpa alasan karena pada level ini, misalnya madrasah, sebagai salah satu lembaga pendidikan Islam, keberadaannya sangat diminati masyarakat muslim terutama yang berada di daerah pedesaan dan pinggiran. Salah satu contoh madrasah yang berada di daerah pedesaan adalah Madrasah Tsanawiyah Raudhatul Hikam. Madrasah tersebut didirikan oleh Yayasan Pondok Pesantren Raudhatul Hikam pada tahun 2014, berlokasi di Desa Banyu Urip, Kecamatan Praya Barat, Lombok Tengah. Visi madrasah ini adalah "berakhlak al-Qur'an, berwawasan global dan berbudaya lokal". Visi madrasah selanjutnya dibreakdown dalam misinya yang meliputi: 1) Meningkatkan keimanan, ketaqwaan, dan akhlak mulia sebagai dasar untuk membentuk santri yang cerdas, terampil, dan mandiri; 2) Menciptakan suasana yang harmonis dan menyenangkan; 3) Meningkatkan profesionalisme santri, pendidik, dan tenaga kependidikan; 4) Menumbuh kembangkan jiwa dan semangat kompetensi dalam mencapai prestasi.

Madrasah Tsanawiyah ini menerapkan sistem pondok pesantren bagi peserta didiknya. Peserta didik di madrasah adalah santri pada saat yang sama sehingga dalam misi madrasah istilah peserta didik diganti dengan istilah santri. MTs Raudhatul Hikam adalah satu-satunya madrasah berbasis pesantren di Desa banyu Urip. Semenjak berdirinya pada tahun 2014, madrasah ini kini memiliki peserta didik berjumlah 40 anak dan guru sebanyak 17 orang.

Berdasarkan hasil wawancara dengan kepala sekolah madrasah tersebut, diperoleh keterangan bahwa:

"Meskipun latar belakang pendidikan guru-guru yang direkrut di madrasah ini adalah sarjana strata satu, bahkan sebagian besar adalah sarjana pendidikan Islam, namun mereka belum cukup mahir dalam hal pengelolaan kelas dan pengembangan metode pembelajaran. Hal ini kemungkinan besar disebabkan karena kurangnya pengalaman mengajar yang dimiliki para guru yang mayoritas adalah fresh graduate. Sementara, misi sekolah ini salah satunya adalah meningkatkan profesionalisme pendidik dan tenaga kependidikan dan menciptakan suasana yang haromis dan menyenangkan." 3

Pemaparan tersebut mengindikasikan bahwa masalah kompetensi guru yang terjadi di madrasah ini memerlukan penyelesaian yang tepat dan cepat sehingga madrasah tidak lagi dipersepsikan sebagai lembaga pendidikan yang tidak diperhitungkan oleh masyarakat. Bagaimanapun juga, guru menjadi faktor utama dalam proses pembelajaran yang diselenggarakan oleh lembaga pendidikan. Sependapat dengan Rusman, bahwa sehebat apapun kurikulum, silabus, dan rencana pembelajaran yang telah dibuat dan dirancang,

2 Sutrisno, Pendidikan Islam yang Menghidupkan (Studi Kritis Terhadap Pemikiran Pendidikan Fazlur Rahman), cet. ke- 2 (Yogyakarta: Kota Kembang, 2008), 78-79.

3 Wawancara dengan Bapak Mansur, M. Pd.I, Kepala Mts Raudhatul Hikam, pada tanggal 15 Maret 2018. 
keberhasilannya sangat tergantung pada implementasi rancangan tersebut oleh guru di kelas, karena gurulah yang berinteraksi langsung dengan siswa. ${ }^{4}$

Guru memiliki peran yang sangat penting dan strategis karena guru yang akan menjabarkan rencana pembelajaran ke dalam pelaksanaan pembelajaran dan mengadakan perubahan yang positif pada diri peserta didik. Di antara peran tersebut adalah: memonitor kegiatan belajar peserta didik, memberkan motivasi, menata dan memantau perlaku peserta didik, menyediakan dan menciptakan model-model pembelajaran, membimbing dan menjadi teman diskusi, menganalisis kebutuhan dan interest peserta didik, mengembangkan materi pembelajaran dan menilai performa peserta didik. ${ }^{5}$

Guru dituntut untuk professional dalam menjalankan tugas dan peran sebagai guru. Guru yang professional harus memenuhi standar kompetensi guru. Standar kompetensi guru adalah suatu ukuran yang ditetapkan atau dipersyaratkan dalam bentuk penguasaan pengetahuan dan berperilaku layaknya seorang guru untuk menduduki jabatan fungsional sesuai bidang tugas, kualifikasi, dan jenjang pendidikan. Ruang lingkup standar kompetensi guru meliputi tiga komponen kompetensi: 1) kompetensi pengelolaan pembelajaran yang mencakup, penyusunan perencanaan pembelajaran, pelaksanaan interaksi belajar mengajar, menilai prestasi belajar, dan melaksanakan tindak lanjut hasil penilaian, 2) kompetensi pengembangan potensi yang diarahkan pada pengembangan profesi, dan 3) kompetensi penguasaan akademik, penguasaan wawasan pendidikan dan penguasaaan bahan kajian akademik. ${ }^{6}$

Konsep ideal guru tersebut menjadi kebutuhan mendesak untuk MTs Raudhatul Hikam yang dalam realitasnya sebagaimana diungkapkan kepala madrasah ini bahwa, mayoritas guru di madrasah ini relatif masih belum banyak memiliki pengalaman pengelolaan pembelajaran yang memadai. Oleh karena itu, pengabdian untuk menjadikan Mts Raudhatul Hikam sebagai madrasah binaan UIN Mataram menjadi sangat relevan dilaksanakan.

\section{Metode}

Pengabdian ini merupakan bentuk pendampingan terhadap madrasah binaan fokus pada penguatan kompetensi guru dalam hal pengelolaan pembelajaran aktif. Pengabdi menggunakan model pelatihan atau training dan peer eaching. Sesuai dengan tujuan model pelatihan yakni untuk meningkatkan kompetensi dan keandalan kualitas kerja peserta. Kegiatan ini terfokus untuk memperdalam hal-hal praktis, meningkatkan kualitas dari hal-hal yang sudah dikerjakan dalam rutinitas di tempat kerja. Pertimbangan lain dalam menggunakan model pelatihan adalah karena para guru di madrasah ini hampir seluruhnya alumni fakultas Tarbiyah dan kependidikan lainnya, sehingga pengetahuan mengenai metode-metode pembelajaran telah diperoleh sebelumnya, tinggal bagaimana meningkatkan kemampuan atau menguatkan kompetensi keguruan dalam praktiknya di kelas.

${ }^{44}$ Rusman, Model-Model Pembelajaran: Mengembangkan Profesionalisme Guru (Jakarta: Raja Grafindo Persada, 2006), 109.
${ }^{5}$ Ibid., 110
${ }^{6}$ Ibid., 114-115 
Pelatihan dilaksanakan dalam satu hari terdiri dari tiga sesi, dari pukul 09.00-15.30. Peserta pelatihan terdiri dari guru-guru MTs Raudhatul Hikam dan trainer terdiri dari tim expert pengembangan strategi active learning. Peserta pelatihan diberikan wawasan bagaimana mengidentifikasi gaya belajar peserta didik, apa saja metode pembelajaran aktif dan bagaimana mengembangkan pembelajaran yang mengaktifkan peserta didik sesuai dengan semangat kurikulum 2013, yakni pendekatan saintifik dalam proses pembelajarannya.

Strategi pelatihan berikutnya adalah peer teaching dalam rangka mengevaluasi hasil pelatihan. Semua peserta mempraktikkan pembelajaran dengan menerapkan strategi pembelajaran aktif di dalam kegiatan pembelajarannya. Hal ini ditunjukkan dalam RPP dan praktik mengajar di depan teman sebaya. Trainer dan pengabdi bertindak sebagai pemandu sekaligus penilai kegiatan tersebut dengan metode memberikan umpan balik untuk masingmasing peserta. Bagi peserta yang kurang tepat menerapkan metode atau penyusunan RPP, maka trainer memberikan masukan dan arahan.

\section{Hasil dan Pembahasan}

\section{Tahapan Pengabdian Masyarakat}

Tahapan awal dari kegiatan pengabdian ini adalah observasi dan wawancara kepada pihak terkait di yayasan Raudhatul Hikam. Hasil observasi dan wawancara tersebut merekomendasikan bahwa fokus pengabdian madrasah binaan di yayasan ini adalah penguatan kapasitas guru khususnya guru-guru Madrasah Tasnawiyah. Setelah dilakukan komunikasi dan koordinasi dengan pihak yayasan dan Mts Raudhatul Hikam Banyu Urip. maka kegiatan yang dimaksud dapat dilaksanakan yakni pada tanggal 14 Juli 2018, dengan pertimbangan sebelum peserta didik aktif masuk sekolah.

Pelaksanaan pengabdian ini dilaksanakan dalam dua kali kegiatan yakni kegiatan pelatihan dan kegiatan peer teaching dalam rangka penerapan hasil workshop. Pengabdi menggunakan model pelatihan atau training sesuai dengan tujuan model pelatihan yakni untuk meningkatkan kompetensi dan keandalan kualitas kerja peserta. Kegiatan ini terfokus untuk memperdalam hal-hal praktis, meningkatkan kualitas dari hal-hal yang sudah dikerjakan dalam rutinitas di tempat kerja. Penggunaan model pelatihan lebih sesuai dikarenakan para guru di madrasah ini hampir seluruhnya alumni fakultas Tarbiyah dan kependidikan lainnya, sehingga pengetahuan mengenai metode-metode pembelajaran telah diperoleh sebelumnya, tinggal bagaimana meningkatkan kemampuan atau menguatkan kompetensi keguruan dalam praktiknya di kelas.

Sesuai rencana yang telah dicanangkan pada awal pengajuan kegiatan pengabdian, kegiatan pertama yakni kegiatan pelatihan berhasil dilaksanakan dengan baik pada hari Sabtu tanggal 14 Juli 2018 di aula MTs Raudhatul Hikam, Banyu Urip. Kegiatan pelatihan diampu oleh pemateri ahli dalam bidang pembelajaran aktif yakni Dr. Saparudin, M. Ag., pengampu mata kuliah mikro teaching dan strategi pembelajaran aktif di Jurusan PAI, Fakultas Tarbiyah dan Keguruan UIN Mataram, sekaligus sebagai Ketua Jurusan PAI di Fakultas tersebut. Sementara pengabdi berlaku sebagai pendamping dari pemateri untuk membantu pelaksanaan kegiatan 
pelatihan berjalan tertib dan lancar. Pelatihan dibagi dalam tiga sesi, dua sesi sebelum sholat dhuhur, dan satu sesi setelahnya.

Kegiatan ini disambut baik dan direspon dengan positif oleh pihak Madrasah dengan indikasi bahwa peserta yang hadir sebanyak 19 orang dari seluruh tenaga pendidik dan kependidikan yang ada di MTs Raudhatul Hikam. Selama kegiatan berlangsung, para peserta mengikuti dengan penuh perhatian dan antusias, terbukti banyaknya pertanyaan yang dilontarkan oleh peserta dan tanggapan yang diberikan pemateri. Kegiatan inti pelatihan dimulai setelah acara pembukaan yang berlangsung dari pukul 08.15-08.45 WITA dengan diisi sambutan dari panitia, yakni pengabdi dan ketua yayasan sekaligus sebagai Kepala Madarsah Tsanawiyah tersebut, Bapak Mansyur, QH, M. Pd.I. Acara coffee break merupakan lanjutan rangkaian acara pembukaan hingga pukul 09.00 WITA.

Kegiatan inti pelatihan terdiri dari tiga sesi. Sesi pertama pada pukul 09.00-10.15 WITA, sesi kedua pada pukul 10.15-12.30 WITA, dan sesi ketiga pada pukul 13-30-15.30 WITA. Penjelasan pelatihan menggunakan LCD didukung dengan print-out materi yang dijelaskan untuk memudahkan peserta pelatihan memahami materi yang disampaikan.. Penjelasan juga dilakukan dengan cara mencontohkan strategi active learning yang dimaksud. Peserta dapat mengajukan pertanyaan jika diperlukan. Pada sesi pertama, , pemateri terlebih dahulu menjelaskan bagaimana model-model gaya belajar peserta didik berdasarkan kecenderungan sifat peserta didik, apakah visual, auditorial, atau kinestetik. Penjelasan gaya belajar ini membantu peserta pelatihan lebih menyadari bahwa karakteristik peserta didik yang dihadapinya beragam, oleh karena itu diperlukan multi metode pembelajaran. Pemateri melanjutkan penjelasan gaya belajar dengan konsep pembelajaran aktif yang meliputi dasar filosofis, perubahan paradigma abad 21 , dan apa yang dilakukan guru agar pembelajaran aktif. Materi pada sesi pertama lebih bersifat teoritis, sehingga peserta pelatihan tidak banyak bertanya. Pertanyaan yang diajukan peserta, Bapak Khairudin misalnya, lebih banyak meminta penjelasan arti istilah-istilah visual, auditorial dan kinestetik. Pemateri kembali menjelaskan pengertian macam-macam gaya belajar dengan contoh-contohnya satu persatu. Bapak Syamsudin melontarkan pertanyaan mengenai faktor-faktor yang mempengaruhi keaktifan peserta didik dalam kegiatan pembelajaran. Menurut pemateri, faktor guru yang kurang dapat mengelola pembelajaran adalah sebagai faktor utamamnya. Kalaupun masih terdapat kesulitan belajar pada satu dua orang peserta didik mungkin ada faktor gangguan fisik atau psikis lainnya yang memerlukan penanganan tersendiri. Demikian sesi pertama berakhir dengan tanya jawab sebagai refleksi sesi tersbut.

Sesi ke dua merupakan sesi penjelasan meode-metode pembelajaran aktif yang dapat diterapkan dalam pembelajaran pada umumnya dan khususnya di tingkat MTs. Metode pertama adalah metode card short (mensortir kartu).. Pengabdi telah mempersiapkan media atau perlengkapan yang dibutuhkan untuk memeragakan metode-metode pembelajaran aktif. Kartu-kartu dipotong dari kertas manila dan diberi pernyataan serta kategori sebagai media dari metode card sort. Pada awal penjelasan, beberapa guru masih belum memahami secara jelas maksud dan cara menerapkan metode card sort, namun dengan adanya media yang disediakan 
dan contoh peragaan oleh pemateri dan pengabdi, maka semua peserta dapat memahami dan ikut terlibat mempratikannya.

Metode kedua adalah metode Index Card Match, yaitu mencocokkan dua potongan kertas. Metode ini merupakan metode berpasangan, dan guru-guru diberikan kesempatan untuk membuat pertanyaan dan jawaban sesuai mata pelajaran masing-masing. Metode ini tidak sulit difahami dan dipraktikkan oleh guru, meskipun untuk mata pelajaran tertentu, seperti yang dialami Ibu Muslimah yang mengajar SBK. Dengan bantuan pemateri akhirnya ibu guru ini dapat menerapkan metode ini.

Metode berikutnya menjadi pembahasan yang mendapatkan perhatian lebih dari peserta pelatihan karena terkait dengan gambar, metode Poster Session. Peserta didik membuat gambar yang sesuai dengan materi pembahasan sehingga lebih mudah diingat. Guru fikih, Bapak Yahya tampil sebagai contoh penerapan metode ini. Gambar makanan-makanan haram mendapatkan komentar beragam dari guru-guru lain. The Power of Two merupakan metode berikutnya yang dibahas dan dipraktikkan. Sesuai tujuan metode ini, yakni untuk mendorong kepekaan peserta didik bahwa bekerjasama adalah hal penting. Metode ini perlu dilatihkan karena kerjasama positif antar peserta didik seperti ini masih jarang diterapkan dalam pembelajaran. Peserta pelatihan pun terlihat masih kurang terampil menerapkan metode ini karena guru-guru juga jarang mengadakan kerjasama dalammelaksanakan sesuatu pekerjaan. Sesi kedua berakhir pada pukul 12.30 .

Sesi ketiga dilanjutkan setelah istirahat, sholat dan makan siang kuarang lebih satu jam. Sesi ini merukan lanjutan dan pengembangan strategi pembelajaran aktif seperti metode jigsaw, yang agak sulit difahami oleh guru-guru. Metode ini sedikit lebih rumit penjelasan dan praktiknya karena lebih panjang langkah-langkahnya disbanding metode-metode sebelumnya. Perlibatan banyak orang dalam berkelompok membuat jigsaw relatif dianggap sulit oleh guru. Metode ini merupakan pengembangan strategi pembelajaran yang menuntut keseriusan tinggi dari peserta didik karena mereka dituntut dapat menjelaskan konsep yang dipelajarinya kepada sesama kelompoknya. Namun demikian, metode ini dapat dicontohkan oleh pemateri dengan melibatkan peserta dengan tidak sulit. Metode lain yang bersifat kelompok adalah role model, snowballing, poster coment dan active debate. Semua metode tersebut, dalam pelaksanaannya melibatkan kerjasama kelompok, baik untuk memainkan model, bertukar pendapat dari kelompok kecil menjadi kelompok besar (snowballing), mengomentari secara kelompok gambar yang ditampilkan guru, dan debat aktif yang dilakukan oleh dua kelompok besar dalam satu kelas mengenai isu tertentu yang diajukan guru. Adapun metode yang bersifat individual adalah every one is a teacher here yang menuntut kemampuan personal peserta didikdalam memahami konsep tertentu. Adanya pemberian kesempatan yang sama untuk setiap peserta didik membuat semua peserta didik merasa lebih dihargai dan percaya diri. Demikian pelatihan sehari selesai dilaksanakan sampai pukul 16.00 .

Tahap kedua dari kegiatan pengabdian-dampingan madrasah ini berupa kegiatan peer teaching. Kegiatan ini direncanakan untuk dilaksanakan satu pecan setelah pelatihan, namun dikarekan oleh situasi dan kondisi madrasah yang akan dimulai pembangunan gedung baru dalam beberapa hari lagi, ditambah dengan aktifnya peserta didik MI dan RA pada minggu 
berikutnya, sehingga kondisi tidak kondusif untuk dilaksanakannya peer teaching, maka disepakati bersama bahwa kegiatan yang dimaksud dilaksanakan pada hari berikutnya dengan konsekuensi semua peserta menyiapkan RPP dan siap mempraktikkannya.

Kegiatan dimulai pukul 08.30 dan peserta telah mempersiapkan diri untuk unjuk kerja di depan teman-teman sebaya. Pesita pertama yang maju ke depan kelas adalah Ahmad Tohri, guru mata pelajaran TIK. Realitas yang terjadi, setelah beberapa waktu, ternyata bapak guru ini belum menerapkan metode pembelajaran aktif. Hal ini dapat dibaca dari RPP yang disusun masih belum mencerminkan adanya penerapan metode pembelajaran aktif, demikian juga ketika tampil mengajar, masih menggunakan model pembelajaran konvensional, menjelaskan dengan ceramah dan melontarkan pertanyaan untuk dijawab. Pokok bahasannya adalah jenis sarana TIK zaman dahulu dan sekarang.

Feedback dari penilai adalah perlunya menambahkan metode pembelajaran aktif, karena pokok bahsan tersebut sangat memungkinkan untuk diterapkan metode card sort atau poster comment dan beberapa metode lainnya. Giliran kedua adalah penampilan guru IPA, Abdul Wahid. Berbeda dengan guru pertama, pokok bahasan IPA adalah sistem pencernaan manusia. Guru sangat bersemangat menerapkan metode bervariasi, dimulai dengan sedikit penjelasan mengenai pokok pembahasan dan meminta peserta didik untuk maju mempraktikkan cara mengunyah dan mengeksplorasi jawaban dari peserta lain dalam mengomentari praktik tersebut. Setelah diberi umpan balik, guru kembali menerapkan metode card sort untuk mengetahui tingkat pemahaman peserta didik. Penampilan berikutnya tidak jauh berbeda, guru matematika telah meracang pembelajarannya dengan menerapkan pembelajaran aktif dan mempraktikannya dalam prosess pembelajaran. Haerudin, guru Matematika ini juga menerapkan metode card sort.

Sementara, guru IPA lain, Rul Hasanawati menerapkan metode jigsaw dalam pembelajarannya terkait pokok bahasan klasifikasi makhluk hidup. Kelas dibagi dalam kelompok, kemudian kelompok diutus ke kelompok lain untuk mempelajari materi sejenis, baru kemudian kembali ke kelompok semula untuk mencertakan hasil belajarnya di kelompok ahli. Dengan penerapan metode-metode yang berbeda-beda dalam berbagai topic atau pokok bahasan yang beragam meningkatkan pemahaman guru terhadap konsep pembelajaran aktif dan praktiknya. Pada akhir kegiatan peer teaching tersebut, penilai dan pendamping melakukan kegiatan refleksi untuk mengetahui ketercapaian tujuan kegiatan pelatihan dan peer teaching. Penilai pun menerapkan metode pembelajaran aktif, snowballing dan role play. Pertanyaan yang dibuat meliputi materi pelatihan dan praktik yang diminta adalah mengenai peragaan metode tertentu atau gaya belajar tertentu.

Praktik mengajar berdasar RPP yang telah disusun tersebut menunjukkan adanya perubahan dalam mengelola pembelajaran, meskipun baru mencapai enam puluh persen dari seluruh guru atau sepuluh dari tujuh belas guru yang menerapkan metode pembelajaran aktif. Hasil inilah yang harus ditekankan pada tahap pendampingan, monitoring dan evaluasi.

\section{Partisipasi dan Pelibatan Para Pihak}

Meskipun pengabdian ini merupakan pengabdian individual, namun untuk pelaksanaan program kegiatan pelatihan, pengabdi melibatkan tim pengabdi yang terdiri dari expertsebagai 
trainer dan pembantu teknis lapangan. Expert yang dimaksud adalah dosen pengampu mata kuliah Strategi Pembelajaran dari Fakutas Tarbiyah dan Keguruan, UIN Mataram, berperan sebagai trainer kegiatan pelatihan. Sedangkan tim pembantu teknis lapangan terdiri dari 2 mahasiswa FTK UIN Mataram, bertugas membantu kelancaran teknis proses kegiatan pelatihan.

Tidak cukup dengan tim pengabdi saja, namun pihak lain juga dilibatkan dalam kegiatan pendampingan ini. Pihak terkait yang dimaksud adalah unsur pimpinan yayasan Raudhatul Hikam, unsur pengasuh Pondok Pesantren Raudhatul Hikam dan unsur pengelola Madrasah, kepala madrasah dan tenaga kependidikan di madrasah ini. Pihak-pihak dari unsur yayasan dan pondok pesantren dan pengelola madrasah akan menyebarluaskan hasil kegiatan pelatihan kepada pengurus yayasan lainnya dan pengelola madrasah satu KKM lainnya di wilayah sekitar.

\section{Pendampingan}

Realitas bahwa belum semua guru peserta pelatihan mampu menerapkan strategi dan metode pembelajaran aktif, sebagaimana ditunjukkan oleh hasil peer teaching, maka pengabdi melakukan pendampingan dalam hal ini. Pendampingan direncakan dapat dilaksanakan pada bulan berikutnya, namun dikarenakan kondisi Lombok pasca gempa yang tidak memungkinkan kunjungan dilakukan saat itu, bulan Agustus, maka pendampingan dilakukan dengan model komunikasi dan konsultasi melalui srana WhatApps dan telpon. Kepala madrasah, sebagai alumni S2 PAI UIN Mataram, menjadi mitra pengabdi dalam kegiatan pendampingan ini.

Komunikasi dan konsultasi telah dilakukan dua kali. Guru-guru yang masih belum mampu menerapakan metode-metode yang dilatihkan berkomunikasi terlebih dahulu kepada kepala sekolah dan kepala madrasah meneruskan kepada pengabdi persoalan-persoalan terkait hal tersebut. Jika kepala madrasah, telah dapat mengatasi persoalan tersebut maka pengabdi cukup diberi laporannya. Namun, jika ada masalah yang belum bisa diselesaikan terkait pengelolaan kelas, maka kepala madrasah berkonsultasi kepada pengabdi dan pengabdi memberikan alternatif jalan keluar. Sebagai contoh, pada bulan Agustus, pengabdi menanyakan masalah yang dihadapi guru-guru di kelas pasca gempa, terkait pengelolaaan pembelajaran dan jawaban kepala madrasah adalah tidak ada persoalan bararti, karena lokasi madrasah tidak terdampak gempa. Oleh karena itu, justru guru-guru mulai menerapkan metode-metode yang dilatihkan di kelas-kelas dan ini dikemukakan oleh para peserta didik yang merasa semangat mengikuti pelajaran di kelas.

Mengenai RPP yang belum terlihat menerapkan pembelajaran aktif, maka pengabdi memberikan saran dan masukan kepada guru yang bersangkutan untuk memperbaikinya dan menerapkannya di kelas. Kepala sekolah mengecek hasil kerja guru-guru tersebut dan mengkonsultasikan kepada pengabdi. Hal ini dilakukan pada bulan September. Kepala madrasah selalu mengkomunikasikan perkembangan yang terjadi di madrasah terkait pembelajaran di kelas. Kepala madrasah mengungkapkan bahwa kegiatan pelatihan semacam ini perlu dilakukan kembali dalam aspek lain yang menyangkut profesionalitas guru atau managemen madrasah lainnya. Sebagai madrasah yang masih cukup muda usianya, madrasah memerlukan pendampingan yang berkelanjutan.

\section{Monitoring dan Evaluasi}

Kegiatan menitoring dan evaluasi untuk model kegiatan madrasah binaan ini tidak dapat secara terperinci terpisah dari model pendampingan kegiatan. Bahkan pada kegiatan peer 
teaching yang telah dilakukan pada awal kegiatan sebenarnya merupakan model evaluasi kegiatan secara tidak langsung. Kegiatan tersebut menjadi evaluasi pertama dari kegiatan pelatihan sebelumnya. Evaluasi berikutnya adalah pada saat monitoring yang dilakukan saat guru melakukan proses belajar-mengajar di kelas masing-masing sebulan setelah kegiatan pelatihan dilaksanakan. Hasil dari monitoring dan evaluasi menunjukkan bahwa hampir semua guru mampu menerapkan pembelajaran aktif di dalam kelas. Antusias guru dan peserta didik terlihat di dalam kelas mengikuti pembelajaran. Guru yang belum terampil menggunakan metode pembelajaran aktif adalah karena masih ragu-ragu untuk memilih mana metode yang tepat untuk diterapkan karena pokok bahasannya dirasa tidak sesuai dengan metode-metode yang dilatihkan.

Monitoring dan evaluasi terakhir menunjukkan adanya hasil yang lebih baik, dalam arti bahwa guru-guru yang semula masih ragu-ragu menggunakan multi metode tidak lagi merasa canggung memilih metode karena dapat dikombinasi dengan metode-metode lain disesuaikan karakteristik pokok bahasan materi pelajaran yang dibahas di kelas. Dengan demikian, menurut pengakuan kepala madrasah bahwa manfaat dan dampak positifnya sangat besar untuk lembaga, semangat guru dan peserta didik menjadi spirit pengembangan madrasah ke depan.

\section{Kesimpulan}

Kegiatan pengabdian masyarakat madrasah binaan di MTs Raudhadul Hikam Banyu Urip dapat dialaksanakan dengan lancar pada bulan Juli 2018. Kegiatan meliputi pelatihan sehari "Penguatan Kapasitas Guru Madrasah Melalui Program Pelatihan Pengembangan Strategi Active Learning Di Madrasah Tsanawiyah Raudhatul Hikam NW Banyu Urip Praya Barat", dan kegiatan Peer Teaching Pengembangan Strategi Active Learning. Kegiatan pelatihan dan kegiatan peer teaching diikuti oleh 19 peserta yang terdiri dari seluruh tenaga pendidik dan kependidikan di madrasah tersebut. Kegiatan pelatihan dilaksanakan sehari, terdiri dari tiga sesi dengan materi mencakup macam-macam gaya belajar dan konsep pembelajaran aktif, multi metode pembelajaran aktif dan pengembangan strategi pembelajaran aktif. Hasil pelatihan dapat dilihat pada hasil kegiatan peer teaching.

Berdasarkan hasil kegiatan peer teaching, yakni praktik mengajar di depan teman sebaya, menunjukkan bahwa enam puluh persen guru atau sepuluh dari tujuh belas guru mampu menerapkan metode pembelajaran aktif. Hasil inilah yang ditindak lanjuti pada tahap pendampingan dan dipantau pada monitoring dan evaluasi kegiatan pengabdian. Hasil monitoring dan evaluasi terakhir menunjukkan adanya peningkatan kemampuan guru dalam pengelolaan kelas sesuai pelatihan dan adanya perbaikan penyusunan RPP sesuai saran masukan pada kegiatan pendampingan. Pelaksanaan kegiatan pengabdian masyarakat madrasah binaan ini memberikan dampak positif signifikan terhadap peningkatan kapasitas guru-guru di MTs Raudhatul Hikam tersebut. 


\section{Referensi}

Azyumardi Azra dan Jamhari, "Pendidikan Islam Indonesia dan Tantangan Globalisasi: Perspektif Sosio_Historis", dalam Jajat Burhanudin dan Dian Afrianti, Mencetak Muslim Modern, Peta Pendidikn Islam Indonesia, Jakarta: Raja Grafindo Persada, 2006.

Sutrisno, Pendidikan Islam yang Menghidupkan (Studi Kritis Terhadap Pemikiran Pendidikan Fazlur Rahman), cet. ke- 2, Yogyakarta: Kota Kembang, 2008.

Rusman, Model-Model Pembelajaran: Mengembangkan Profesionalisme Guru Jakarta: Raja Grafindo Persada, 2006.

Pollio, H.R., "What Students Think About and Do in College Lecture Classes" dalam TeachingLearning Issues No. 53, Knoxville, Learning Research Centre, University of Tennesse, 1984.

McKeachie W., Teaching Tips: A Guidebook for the Beginning College Teacher, Boston, D.C. Health, 1986.

Silberman, Mel, Active Learning, 101 Strategi Pembelajaran Aktif, (terjemahan Sarjuli et al.), Yogyakarta: YAPPENDIS, 2004.

Mulyasa, E., Kurikulum Berbasis Kompetensi (KBK), Konsep, Karakteristik dan Implementasi, Bandung: Remaja Rosdakarya, 2004. 